\title{
Maspin inhibits MCF-7 cell invasion and proliferation by downregulating miR-21 and increasing the expression of its target genes
}

\author{
SHAO-XIN HUANG ${ }^{1,2^{*}}$, WEN-YAN FAN ${ }^{1,2^{*}}$, LING WANG $^{1,2^{*}}$, HUI LIU $^{3}$, \\ XIN WANG ${ }^{1,2}$, HAO ZHAO $^{1,2}$ and WEN-BIN JIANG ${ }^{1,2}$ \\ ${ }^{1}$ Department of Social Science and Public Health, School of Basic Medical Science, Jiujiang University, \\ Jiujiang, Jiangxi 332000; ${ }^{2}$ Urban Agglomeration in The Middle Reaches of The Yangtze River and \\ Nanchang-Jiujiang Development Research Center, Jiujiang, Jiangxi 3320005; ${ }^{3}$ Clinical Skills Center, \\ Clinical Medical College, Jiujiang University, Jiujiang, Jiangxi 332000, P.R. China
}

Received April 29, 2016; Accepted July 3, 2017

DOI: $10.3892 /$ ol.2020.11360

\begin{abstract}
Maspin has been identified as a tumor suppressor gene in breast cancer, but the underlying regulatory mechanisms remain unclear. In the present study, maspin pcDNA was transfected into MCF-7 cells. microRNA (miR) microarray and reverse transcription-quantitative polymerase chain reaction was used for analysis; the results demonstrated that maspin may inhibit miR-10b, miR-21 and miR-451 expression in MCF-7 cells. In addition, maspin increased the expression of certain miR-21 target genes (phosphatase and tensin homolog, programmed cell death 4 and B-cell lymphoma-2), miR-10b target gene (Homeobox D10; HOXD10) and miR-451 target gene (multidrug resistance protein 1). Furthermore, the results of the present study revealed that decreased expression of miR-21 suppressed the invasion and proliferation of MCF-7 cells. Therefore, in the present study, it was hypothesized that as a tumor-suppressor gene, the potential molecular mechanism of maspin include down-regulating the expression of miR-21 and increasing the expression of specific miR-21 target genes.
\end{abstract}

\section{Introduction}

Breast cancer is the second leading cause of cancer-related mortality, following lung cancer, in women globally, with almost one third of cases resulting in mortality (1). It was reported that the expected numbers of new breast cancer cases

Correspondence to: Ms. Hui Lui, Clinical Skills Center, Clinical Medical College, Jiujiang University, 17 Lufeng Road, Jiujiang, Jiangxi 332000, P.R. China

E-mail: 652274500@qq.com

${ }^{*}$ Contributed equally

Key words: maspin, microRNA, breast cancer, proliferation, invasion in 2012 was 230,480 , which is expected to account for $30 \%$ of all new cancer cases among women (2). Understanding the underlying molecular mechanisms of tumor suppressor genes and then effectively incorporating this knowledge into a clinical environment has long been a focus of cancer research and translational medicine.

Maspin is a non-inhibitory member of the serine protease inhibitor super family; previous studies have demonstrated that maspin may be useful in clinical practice $(3,4)$. Maspin is typically silenced or expressed at a decreased level in breast cancer cells, and has long been considered a type II tumor suppressor that regulates cell adhesion and invasion (5). The MCF-7 cell line originated from human breast cancer cells and has retained a number of characteristics of differentiated mammary epithelial cells (6).

microRNAs (miRNAs) are highly conserved noncoding RNA molecules that are approximately 17-25 nucleotides in length. They control gene expression at the post-transcriptional level via interacting with a specific target mRNA (7-9). miRNAs are regulatory molecules recognized to be aberrantly expressed in cancer and contribute to various aspects of tumor biology, including the proliferation and invasive abilities of tumors (10). In addition, miRNAs may provide insights into the molecular pathogenesis of breast cancer (11). Although maspin is considered to be a tumor suppressor gene, the underlying molecular mechanisms of maspin-induced inhibition of breast cancer cell proliferation and invasion remains unknown.

In the present study, maspin expression was induced in MCF-7 cells using cloning techniques. Subsequently, the differential expression of miRNA was determined between the maspin and mock groups using gene chip analysis. Furthermore, the effect of maspin on the corresponding target genes of miR-21 gene was investigated. The present study aimed to identify how maspin affected the proliferation and differentiation of MCF-7 cells.

\section{Materials and methods}

Cell culture. MCF-7 cells were purchased from the American Type Culture Collection (Manassas, VA, USA). TRIzol ${ }^{\circledR}$ 
was purchased from Invitrogen (Thermo Fisher Scientific, Inc., Waltham, MA, USA) and cell culture was conducted according to the method described previously (12). MCF-7 cells were cultured in Dulbecco's modified Eagle's medium supplemented with $10 \%$ fetal bovine serum (both from Gibco; Thermo Fisher Scientific, Inc.) at $37^{\circ} \mathrm{C}$ in an atmosphere containing $5 \% \mathrm{CO}_{2}$.

Plasmid transfection. Total mRNA was extracted from MCF-7 cells using TRIzol with NanoDrop ${ }^{\mathrm{TM}} 2000$ (Thermo Fisher Scientific, Inc.). Following the quantification, $500 \mu \mathrm{g}$ total RNA was reverse-transcribed with a cDNA Reverse Transcription kit (Beijing TransGen Biotech Co., Ltd., Beijing, China), according the manufacturer's protocols. The experiment used $50 \mu \mathrm{lPCR}$ reaction volume and $500 \mathrm{ng}$ cDNA template with Trans-start Tip Green qPCR SuperMix (Beijing TransGen Biotech Co., Ltd.), and the method was performed under the following conditions: Denaturing for $30 \mathrm{sec}$ at $94^{\circ} \mathrm{C}$; annealing for $30 \mathrm{sec}$ from $65^{\circ} \mathrm{C}$ to $60^{\circ} \mathrm{C}$, and decreasing at $0.5^{\circ} \mathrm{C}$ each cycle, and extending for $3 \mathrm{~min}$ at $72^{\circ} \mathrm{C}$ for each 10 cycles; annealing for $30 \mathrm{sec}$ at $60^{\circ} \mathrm{C}$, and extending for $3 \mathrm{~min}$ at $72^{\circ} \mathrm{C}$ for 25 cycles, and a final extension at $72^{\circ} \mathrm{C}$ for $5 \mathrm{~min}$. Additionally the following primers were used in PCR: Forward, 5'-GGAATTCCCCGCAATGGATGCCCTGCA ACTAG-3' and reverse, 5'-CCCTCGAGACTTAAGGAG AACAGAATTTGCCAA-3'. The forward primers contain an EcoRI restriction enzyme site, and the reverse primers contain a XhoI restriction enzyme site. Human maspin cDNA was inserted into a $\mathrm{pEF}$ expression vector (Promega Corporation, Madison, WI, USA) using restriction enzyme digestion with $E c o$ RI and $\mathrm{XbaI}$, and the pcDNA3.1-maspin contained a cDNA encoding amino acids 1-375 of human maspin. The vector pcDNA3.1 alone was used as a negative control. Transient transfection of cells with plasmids was performed using Lipofectamine ${ }^{\circledR} 2000$ (Invitrogen; Thermo Fisher Scientific, Inc.), according to the manufacturer's protocol, and $20 \mu \mathrm{g}$ DNA was diluted in $200 \mu 1$ Lipofectamine ${ }^{\circledR} 2000$ reagent in $60 \mathrm{~mm}$ well. Each experiment was conducted immediately following transfection.

Cell viability assay. For the quantitative determination of the proliferation of MCF-7 cells, a Cell Counting Kit-8 (CCK-8; Nanjing Jiancheng Bioengineering Institute, Nanjing, China) assay was performed. Following the transfection of maspin pcDNA into MCF-7 cells for $24 \mathrm{~h}$, the cells were washed, counted and seeded at a density of $4 \times 10^{5}$ cells $/ \mathrm{ml} /$ well in 96-well plates. CCK-8 solution was added and the cells were incubated for an additional $4 \mathrm{~h}$ at $37^{\circ} \mathrm{C}$ in a $5 \% \mathrm{CO}_{2}$ incubator. Cell proliferation was determined using a spectrophotometer at an absorbance of $450 \mathrm{~nm}$. The experiments were repeated $\geq 5$ times/group.

In vitro invasion assay. The maspin-MCF-7 cells were seeded at a density of $1 \times 10^{4}$ cells/well in Dulbecco's modified Eagle's medium with $10 \%$ fetal bovine serum (both from Gibco; Thermo Fisher Scientific, Inc.) in Matrigel-coated invasion chambers in a 24-well plate (BD Biosciences, Franklin Lakes, NJ, USA) and Matrigel solution was polymerized in Transwell inserts for $45 \mathrm{~min}$ at $37^{\circ} \mathrm{C}$. Cells $\left(5 \times 10^{5}\right)$ were plated in the top chamber in Dulbecco's modified Eagle's medium without serum, and Dulbecco's modified Eagle's medium supplemented with $10 \%$ fetal bovine serum (Gibco; Thermo Fisher Scientific, Inc.) was placed into the lower chamber. Following this, cells were incubated for an additional $4 \mathrm{~h}$ at $37^{\circ} \mathrm{C}$ in an atmosphere containing $5 \% \mathrm{CO}_{2}$, and then for $24 \mathrm{~h}$ at $37^{\circ} \mathrm{C}$, the cells on the upper membrane surface were removed with a cotton swab. Cells that invaded to the lower side of the membrane were stained with $0.1 \%$ crystal violet at room temperature for $20 \mathrm{~min}$ and fixed with $4 \%$ paraformaldehyde at room temperature for $20 \mathrm{~min}$, and then stained by $0.1 \%$ crystal violet for another $20 \mathrm{~min}$ at $37^{\circ} \mathrm{C}$. The mean number of invasive cells were counted under a $\times 100$ fluorescence microscope using four separate fields of view for each well. The experiments were repeated $\geq 3$ times.

miRNA microarray. miRNA microarray analysis was performed as previously described (13). Total RNA was isolated from cells with TRIzol reagent and quantified with NanoDrop 2000 (Thermo Fisher Scientific, Inc.). Following the quantification, $500 \mu \mathrm{g}$ total RNA was reverse-transcribed with a cDNA Reverse Transcription kit (Beijing TransGen Biotech Co., Ltd.), and miRNA was isolated using the mirVana ${ }^{\mathrm{TM}}$ miRNA isolation kit (Ambion; Thermo Fisher Scientific, Inc.). cRNA was synthesized by using the 3'IVT Express kit (Affymetrix; Thermo Fisher Scientific, Inc.), according to the manufacturer's protocol. The fragmented labeled cRNA was applied using the MicroRNA 2.0 Array (Affymetrix; Thermo Fisher Scientific, Inc.), and hybridized at $45^{\circ} \mathrm{C}$ for $18 \mathrm{~h}$ using the GeneChip Hybridization Oven 640 (Affymetrix; Thermo Fisher Scientific, Inc.), according to the manufacturer's protocols. The arrays were scanned using a GeneChip Scanner 3000 (Affymetrix; Thermo Fisher Scientific, Inc.). The expression levels of each miRNA in the array were compared and normalized with the mean using Partek GS 6.5 (Partek Inc., St. Louis, MO, USA). Average-linkage hierarchical clustering of the data was applied by using the Cluster (2.20; http://rana. lbl.gov/EisenSoftware.htm), and for cluster analysis, log transformed data were centered to the mean values of each gene expression (14) and the results were displayed using TreeView graphical (1.6.6) analysis (15).

Quantitative PCR ( $q P C R$ ) for $m R N A$. Total RNA was isolated from MCF-7 cells with TRIzol reagent, according to the manufacturer's protocol, using 1,000 $\mu \mathrm{l}$ TRIzol and incubated for $5 \mathrm{~min}$ at room temperature. Subsequently, $200 \mu \mathrm{l}$ chloroform was added, vortexed for $15 \mathrm{sec}$, and incubated for 2-3 min at room temperature. This was followed by centrifugation at $12,000 \mathrm{x} \mathrm{g} \mathrm{at} 4^{\circ} \mathrm{C}$ for $15 \mathrm{~min}$. The upper watery phase was removed and 1.5 times its volume (100\%) ethanol was added. Additionally, $700 \mu 1$ of this mixture were placed in RNeasy Mini spin column in $2 \mathrm{ml}$ collection tube and centrifuged at $8,000 \mathrm{x} \mathrm{g}$ at room temperature for $15 \mathrm{sec}$. After the mixture had completely passed the column, $700 \mu 1$ of buffer RWT (Qiagen GmbH, Hilden, Germany) was added to each column, and again centrifuged at $8,000 \mathrm{x}$ g at room temperature for $15 \mathrm{sec}$. Then, $500 \mu \mathrm{l}$ buffer RPE was added to the column and centrifuged at $8,000 \mathrm{xg}$ at room temperature for $15 \mathrm{sec}$. The previous process was repeated for $2 \mathrm{~min}$ at $8,000 \mathrm{x}$ g. The column was transferred to a new $1.5 \mathrm{ml}$ collection tube and $50 \mu \mathrm{l}$ RNase-free water was pipetted directly onto the column 
Table I. Primer sequences used in the reverse transcription-quantitative polymerase chain reaction.

\begin{tabular}{ll}
\hline Gene & \multicolumn{1}{c}{ Primer sequences } \\
\hline Maspin & F: 5'-TATCCCTGTTGCCGGTTCA-3' \\
& R: 5'-AGATGGGAGAAGGAATGTCAC-3' \\
U6 & F: 5'-CTCGCTTCGGCAGCACA-3' \\
& R: 5'-AACGCTTCACGAATTTGCGT-3' \\
$\beta$-actin & F: 5'-TCCTCCTGAGCGCAAGTACTC-3' \\
& R: 5'-CTGCTTGCTGATCCACATCTG-3' \\
PTEN & F: 5'-TCGACTACTTGCTTTGTAGA-3' \\
& R: 5'-TTTACAGCCCCGATTGGGCT-3' \\
PDCD4 & F: 5'-TCTCAAATGCCCTTTCATCC-3' \\
& R: 5'-TGGATTAACTGTGCCAACCA-3' \\
Bcl-2 & F: 5'-GCTTTTCCTCTGGGAAGGAT-3' \\
& R: 5'-CCTCCGTTATCCTGGATCCA-3' \\
HOXD10 & F: 5'-ATGTACATGCCACCACCTAGC-3' \\
& R: 5'-TTGCTGTGTAACAGGTTGCTCTA-3' \\
MDR1 & F: 5'-TCACCAAGCGGCTCCGATACAT-3' \\
& R: 5'-CCCGGCTGTTGTCTCCATAGGC-3'
\end{tabular}

PTEN, phosphatase and tensin homolog; PDCD4, programmed cell death 4; Bcl-2, B-cell lymphoma-2; HOXD10, homeobox D10; MDR1, multi-drug resistance gene 1; F, forward; R, reverse.

and centrifuged for $1 \mathrm{~min}$ at $8,000 \times \mathrm{g}$ to elute RNA. The extracted mRNA then stored at $-80^{\circ} \mathrm{C}$ until use. qPCR was performed with an Applied Biosystems StepOne ${ }^{\mathrm{TM}}$ real-time PCR system (Applied Biosystems; Thermo Fisher Scientific, Inc.), and the fast SYBR ${ }^{\circledR}$-Green Master mix (Thermo Fisher Scientific, Inc.) was used for qPCR, according to the manufacturer's protocol. The method of quantification for PCR was calculated with the $2^{-\Delta \Delta \mathrm{Cq}}$ method (16). Phosphatase and tensin homolog (PTEN), programmed cell death 4 (PDCD4) and B-cell lymphoma-2 (Bcl-2) gene expression was detected and the primers used are listed in Table I. Data are presented as the relative expression levels compared with $\beta$-actin.

Reverse transcription ( $R T$-) $q P C R$ for miRNA. Total RNA was isolated from cells by using TRIzol. cDNA was synthesized using the miRNA Reverse Transcription kit $20 \mu 1 \mathrm{RT}$ reactions, incubated for $60 \mathrm{~min}$ at $37^{\circ} \mathrm{C}$, followed by $5 \mathrm{~min}$ at $95^{\circ} \mathrm{C}$, according to the manufacturer's instructions (Applied Biosystems; Thermo Fisher Scientific, Inc.). A total of $20 \mathrm{ng}$ cDNA was used as a template in a total volume of $20 \mu \mathrm{l}$ reaction with the following conditions: Denaturation at $95^{\circ} \mathrm{C}$ for $15 \mathrm{~min}$ followed by 40 cycles of $94^{\circ} \mathrm{C}$ for $15 \mathrm{sec}, 55^{\circ} \mathrm{C}$ for $30 \mathrm{sec}$, and $72^{\circ} \mathrm{C}$ for $34 \mathrm{sec}$, in which fluorescence was acquired and detected via Real-time PCR system (Qiagen $\mathrm{GmbH}$ ). After the PCR cycles, melting curve analyses were performed to validate the specific generation of the expected PCR product small nuclear RNA U6 was used as an endogenous control. Forward and Reverse target sequences are shown in Table I.

A SYBR green miRNA assay was used to quantify the relative expression levels of miR-10b, miR-21 and miR-451, according to the manufacturer's protocol. The primers of miR-10b were 5'-TACCCTGTAGAACCGAATTTG-3' (forward) and 5'-AACTGGTGTCGTGGAGTCGGC-3' (reverse), and the primers of miR-21 were 5'-GCCGCTAGC TTATCAGACT-3' (forward) and 5'-AGTGCAGGGTCCGAG GTA-3' (reverse). The fold-change between the selected genes and U6 transcripts for miRNA was calculated with the $2^{-\Delta \Delta C q}$ method (16). And all reactions were run in triplicate.

Western blot analysis. The method was performed as previously described (17). The antibodies used in the present study were all purchased from Abcam (Cambridge, UK). The membranes were incubated with primary antibodies against maspin (dilution, 1:1,500; catalog no. ab182785), PDCD4 (dilution, 1:1,000; catalog no. ab45124), HOXD10 (dilution, 1:350; catalog no. ab76897), multi-drug resistance gene (dilution, 1:1,500; MDR1; catalog no. ab170904), PTEN (dilution, 1:500; catalog no. ab31392), Bcl-2 (dilution, 1:150; catalog no. ab117115) and $\beta$-actin (dilution, 1:1,000; catalog no. ab8226) at $4^{\circ} \mathrm{C}$ overnight. Briefly, normal or treated cells were harvested on ice with ice-cold lysis buffer containing $10 \mathrm{mM}$ Tris $\mathrm{pH}$ 7.4, $100 \mathrm{mM} \mathrm{NaCl}, 1 \mathrm{mM}$ EDTA, $1 \mathrm{mM}$ EGTA, $1 \mathrm{mM} \mathrm{NaF}, 20 \mathrm{mM} \mathrm{Na}{ }_{4} \mathrm{P}_{2} \mathrm{O}_{7}, 1 \%$ Triton $\mathrm{X}-100$, $10 \%$ glycerol, $0.1 \%$ SDS and $0.5 \%$ deoxycholate, and protease and phosphatase inhibitor cocktails. Samples (30 $\mu$ g protein) were loaded to a $10 \%$ SDS-PAGE gel, fractioned through electrophoresis, and transferred onto nitrocellulose membranes. The membranes were blocked with 5\% BSA and wash the membrane in three washes of TBS with $0.05 \%$ Tween-20 (TBST), 5 min each, then probed with appropriate primary and horseradish peroxidase (HRP)-conjugated rabbit secondary antibodies (dilution, 1:3,000; catalog no. ab150077; Abcam) for $1 \mathrm{~h}$ at room temperature. The membranes were washed three times with TBST, 5 min each. The blots were detected using ECL western blotting detection reagents (catalog no. RPN2109; GE Healthcare, Chicago, IL, USA). The images were captured and analyzed using the UVP gel documentation system (UVP, LLC, Phoenix, AZ, USA).

Statistical analysis. Data are presented as the mean \pm standard deviation. Mean values were compared and P-values were determined using the two-tailed Student's t-test or the Pearson's $\chi^{2}$ test. $\mathrm{P}<0.05$ was considered to indicate a statistically significant difference. All statistical calculations were performed using GraphPad Prism 5 (GraphPad Software, Inc., La Jolla, CA, USA) software and SPSS (version 17.0 for Windows; SPSS Inc., Chicago, IL, USA).

\section{Results}

Maspin inhibits the proliferation and invasion of MCF-7 cells. To assess whether maspin expression was required for the proliferation and invasive properties of MCF-7 cells, human maspin cDNA (1.3 kb full length) was inserted into a pEF expression vector for restriction enzyme digestion with EcoRI and XbaI. Maspin clones were examined using RT-qPCR and western blot analysis. As presented in Fig. 1, the gene and protein expression of maspin were upregulated in maspin cells compared with the mock cells $(\mathrm{P}<0.05)$; therefore, maspin was successfully cloned into the MCF-7 cells (Fig. 1A and B). The expression of maspin 

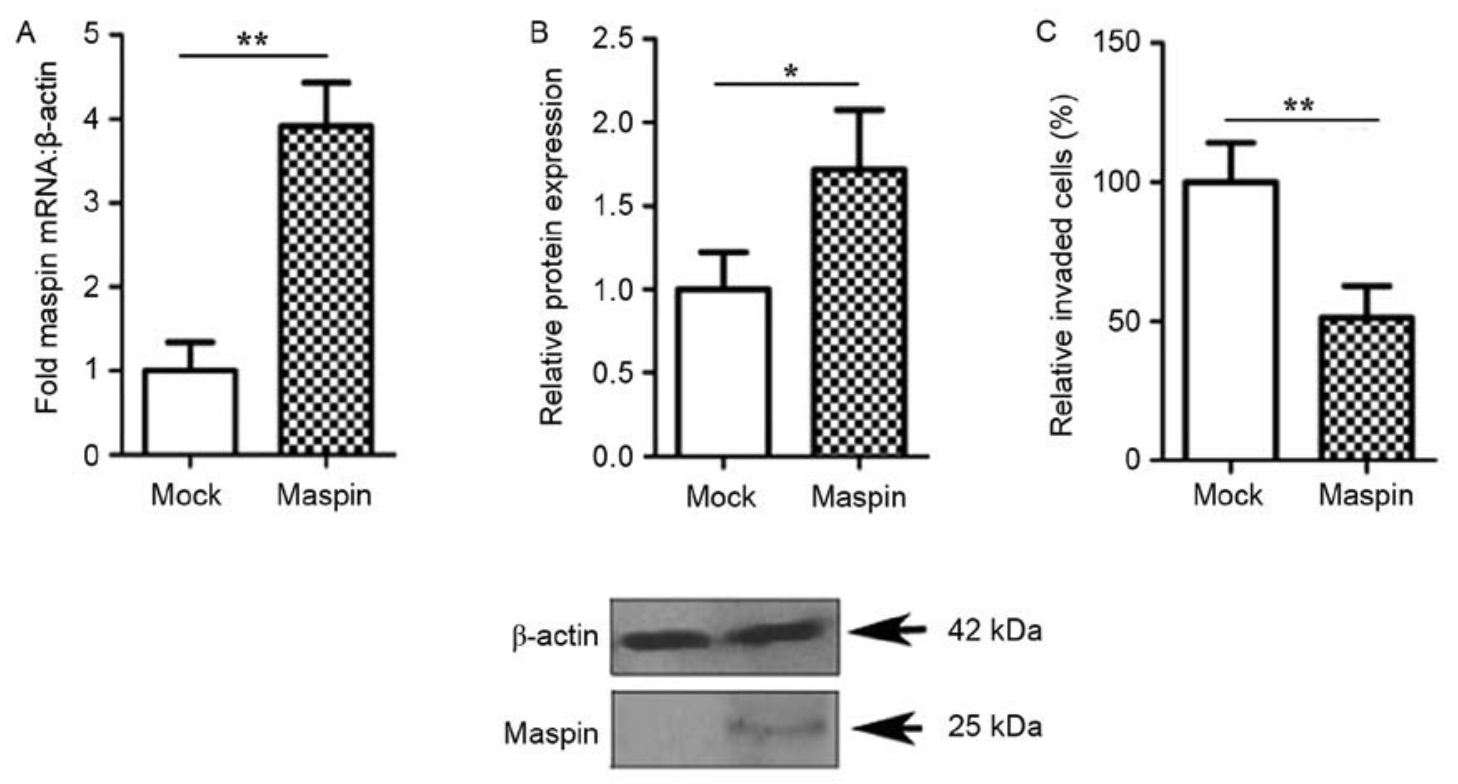

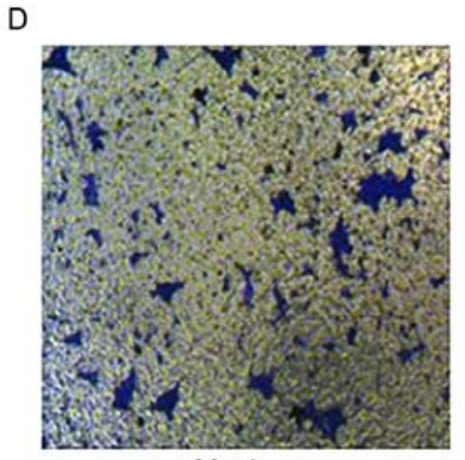

Mock

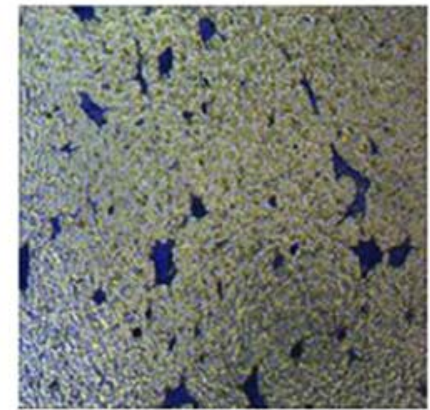

Maspin

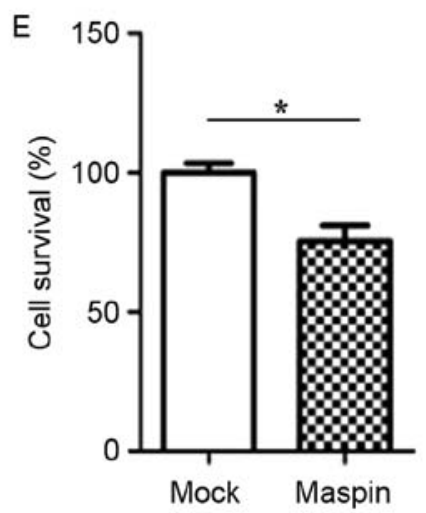

Invasion assay

Figure 1. Maspin inhibits MCF-7 cell proliferation and invasion. Reverse transcription-quantitative polymerase chain reaction and western blot analysis were used to analyze the stable expression of maspin in cell lysates from MCF-7 cells following transfection with maspin or the mock. (A) The maspin mRNA level. (B) Relative maspin protein level. $\beta$-actin was used as the loading control. (C) CCK8. (D) Images (x200 magnification) of representative fields for invasion experiment. (E) Effect of maspin on MCF-7 cell invasion. Values were the average of three separate experiments and data are presented as the mean \pm standard deviation. Student's t-test was for statistical analysis. ${ }^{*} \mathrm{P}<0.05$ vs. the mock; ${ }^{* *} \mathrm{P}<0.01$ vs. the mock. CCK8, Cell Counting Kit- 8 .

in $\mathrm{MCF}-7$ resulted in a significant reduction in the invasion (Fig. 1C and $\mathrm{D} ; \mathrm{P}<0.05$ ) and proliferation (Fig. 1E; $\mathrm{P}<0.05)$ of MCK-7 cells, when compared with the mock cells.

Maspin downregulates miR-10b, miR-21 and miR-451 expression in MCF-7 cells. Using miRNA array analysis, it was identified that maspin altered the expression of a number of microRNAs in MCF-7 cells, including miR-21, miR-10b and miR-451 (Fig. 2A). The aberrant expression of miR-21, miR-10b and miR-451 in association with tumorigenesis, tumor growth and tumor metastasis has been identified in distinct types of malignancy; therefore, in the present study, the expression of these miRNAs in MCF-7 cells, that had been stably or transiently transfected with maspin, were analyzed. Using qPCR, with $\beta$-actin as an endogenous control, it was revealed that miR-21, miR-10b and miR-451 were significantly downregulated between 2- and 2.4-fold by maspin (Fig. 2B; $\mathrm{P}<0.05$ ).

Maspin increases the protein expression of $m i R-21, m i R-10 b$ and miR-451 target genes in MCF-7 cells. In order to explore whether maspin affected the proliferation and differentiation of MCF-7 cells, the effect of maspin on the target genes of miR-21, miR-10b and miR-451 was investigated. Compared with the mock group, the expression levels of the target genes of miR-21 in maspin pcDNA group were significantly different $(\mathrm{P}<0.05)$. As presented in Fig. 3, maspin increased the mRNA expression of PTEN, PDCD4 and Bcl-2 by between 1.5- and 2.0-fold (Fig. 3A). Fig. 3B and C demonstrate that maspin significantly increased the expression of HOXD10 $(\mathrm{P}<0.01)$ and MDR1 $(\mathrm{P}<0.05)$. Additionally, the protein expression levels of PTEN, PDCD4 and Bcl-2 in the mock and maspin pcDNA groups (Fig. 3D-F). The relative expression is depicted in Fig. 3G-I.

miR-21 promotes the proliferation and invasion of $M C F-7$ cells. To determine whether the aforementioned miRNAs may function as oncogenes, the effect of suppressing miR-21, miR-10b and miR451 on cell proliferation and invasion was investigated. An anti-miR-21 inhibitor was used to inhibit the expression of miR-21. The anti-miR-21 inhibitor is a 

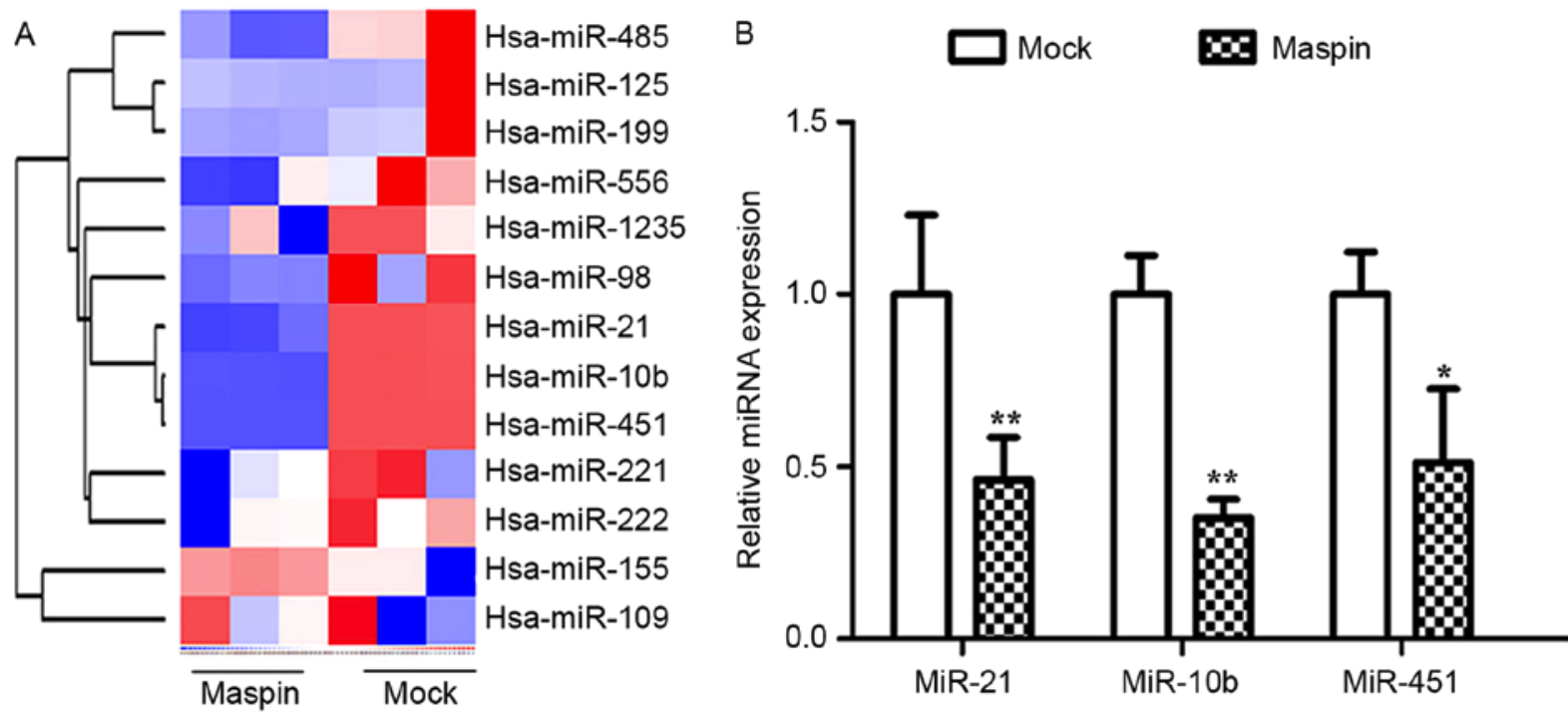

Figure 2. Transfecting with maspin exhibited decreased expression levels of miR-21, miR-10b and miR-451. (A) Hierarchical clustering of the differentially expressed miRNA genes (determined using an analysis of variance) in the mock-MCF-7 and maspin-MCF-7 cells. Rows, miRNA; columns, independent biological replicates. Red indicates increased level of expression and blue indicates decreased level of expression. (B) Relative miRNA expression of miR-21, miR-10b and miR-451 in mock and maspin-transfected MCF-7 cells was examined using the reverse transcription-quantitative polymerase chain reaction. Values were the average of three separate experiments and data are presented as the mean \pm standard deviation. Differences between two groups were assessed by two-tailed Student's test. ${ }^{*} \mathrm{P}<0.05$ vs. the mock; ${ }^{* *} \mathrm{P}<0.01$ vs. the mock. miR, microRNA; hsa, human.

sequence-specific and chemically modified oligonucleotide to specifically target and knockdown miR-21 molecule. TaqMan real-time PCR revealed that anti-miR-21 significantly reduced miR-21 level (Fig. 4A; $\mathrm{P}<0.05$ ), indicating that anti-miR-21 is efficiently introduced into the cells and knock down miR-21. A significant decrease $(\mathrm{P}<0.05)$ was observed in the proliferation and invasion of MCF-7 cells, following transfection of anti-miR-21 inhibitor (Fig. 4B and C). Additionally, the expression of miR-10b was down-regulated in MCF-7 cells following the use of an antisense anti-miR-10b inhibitor, which resulted in a 2.6-fold decrease in the gene expression levels of miR-10b (Fig. 4D; $\mathrm{P}<0.05$ ). The results of the present study suggest that the transfected antisense anti-miR-10b inhibitor achieved $>50 \%$ inhibition of miR-10b. Fig. $4 \mathrm{E}$ and $\mathrm{F}$ demonstrate that miR-10b function is required for invasiveness in MCF-7 cells $(\mathrm{P}<0.05)$, but not for the proliferation or invasive ability of these cells $(\mathrm{P}>0.05)$. Following transfection with an anti-miR-451 inhibitor, the expression of miR-451 was significantly downregulated in MCF-7 cells (Fig. 4G; $\mathrm{P}<0.05)$; however, there was no significant difference observed in the proliferation (Fig. 4H) and invasion (Fig. 4I) of MCF-7 cells $(\mathrm{P}>0.05)$. The transfection with anti-miRNA inhibitors resulted in a marked reduction in the invasion (Fig. 4J).

\section{Discussion}

Maspin is a unique member of the serpin (serine protease inhibitor) family; the downregulation of maspin has been associated with the development of breast cancer (18). In the present study, increased maspin gene expression was associated with decreased invasive capacity and increased overall survival in MCF-7 cells, which is consistent with the results of a previous study (19).

miRNAs have been extensively studied in a number of types of cancer; however, the knowledge of the aberrant expression and the association between maspin and miRNAs remains unknown. In the present study, the results revealed an association between increased maspin expression and the downregulation of miR-21, miR-10b and miR-451 in MCF-7 breast cancer cells.

miR-21 regulates genes involved in a number of cellular processes, and has been identified to promote cell proliferation, invasion and migration by downregulating the expression of the tumor-suppressor genes PDCD4 and PTEN $(20,21)$. A previous study revealed that the inhibition of miR-21 may upregulate the expression of Bcl-2 (22), but this remains controversial (23). In the present study, the expression of maspin led to an increase in miR-21 target gene expression in MCF-7 cells, including of PTEN, PDCD4 and $\mathrm{Bcl}-2$. The results of the present study were concordant with those of a prior study (18), demonstrating that maspin inhibits miR-21. To understand the mechanisms by which miR-10b induces tumor invasion and metastasis, HOXD10 was of particular note, as its expression is progressively reduced in breast tumors of increasing degrees of malignancy $(24,25)$. Furthermore, miR-10b has been revealed to promote the migration and invasion of cells via HOXD10 in certain human cancer types (26). The results of the present study demonstrated that maspin may inhibit miR-10b and result in increased levels of HOXD10. Therefore, maspin increased the expression of HOXD10, and the underlying molecular mechanisms may be associated with miR-10b. In addition, inducing the expression of maspin resulted in a decrease in miR451 gene expression; however, the proliferation and invasive abilities of MCF-7 cells were not altered by this regulation of $\mathrm{miR}-451$.

The results of the present study identified that maspin may increase the protein expression of miR-21 target genes. In the present study, following demonstrating that maspin may inhibit miR-21, miR-10b and miR451, it was hypothesized that maspin may affect the properties of MCF-7 cells by decreasing the expression of miR-21 and increasing its target genes. Cells transfected 
A

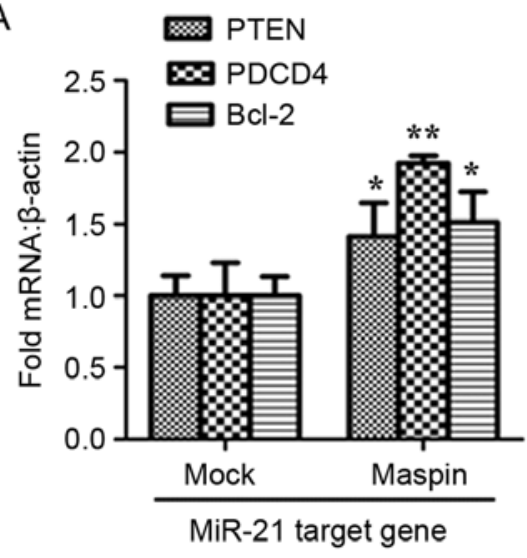

D
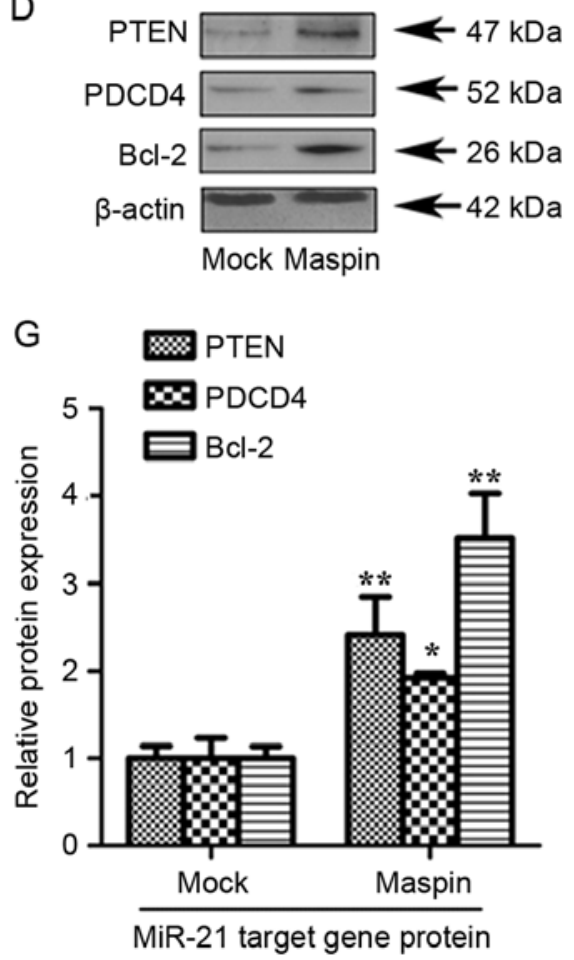
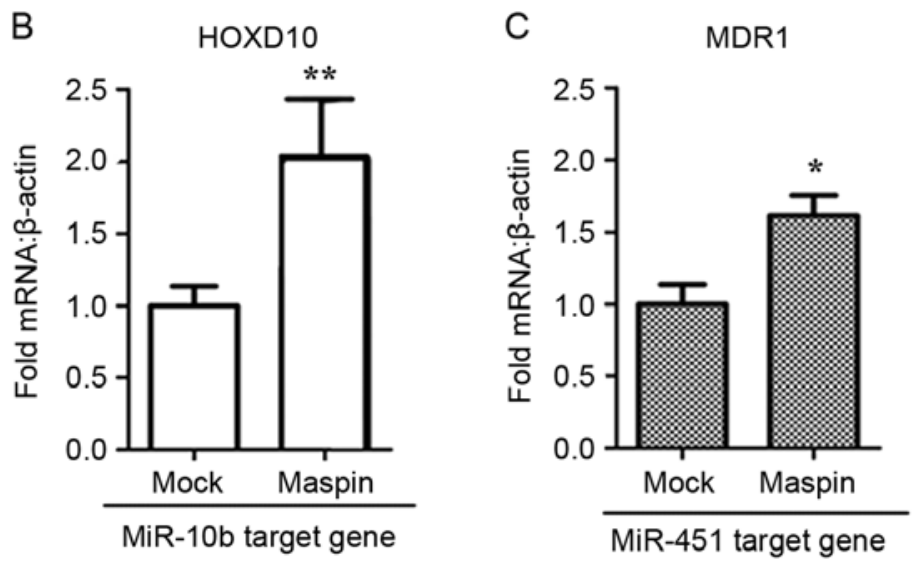

E

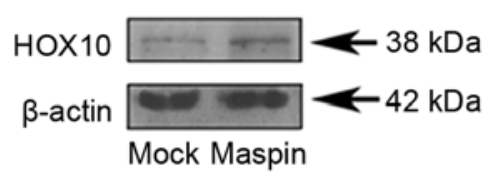

F

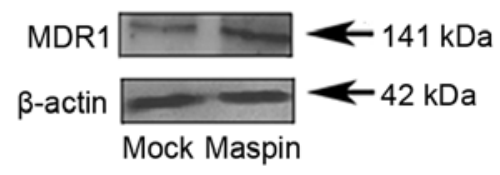

$\mathrm{H}$

HOXD10

।

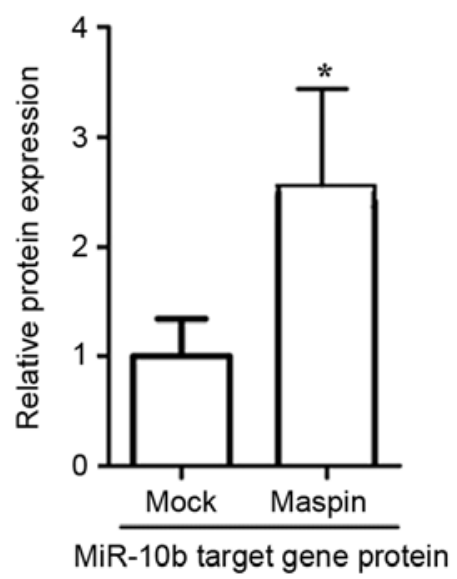

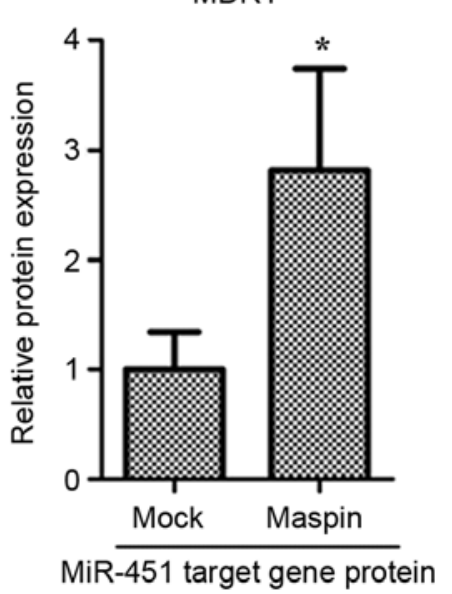

Figure 3. Maspin increases the expression of miR-21, miR-10b and miR-451. MCF-7 cells were transfected with mock or maspin pcDNA as indicated. The specificity of maspin to influence the mRNA of endogenous miR-21, miR-10b and miR-451 target gene was examined using RT-qPCR or western blotting in parallel with the mock group as a negative control. (A) RT-qPCR analysis of (A) miR-21, (B) miR-10b and (C) miR-451 target genes expression in MCF-7 cells transfected with maspin, compared with mock. (D) Western blot analysis of miR-21 target genes in maspin cells, compared with mock cells. (E) Western blot analysis of miR-10b target genes in maspin cells, compared with mock cells. (F) Western blot analysis of miR-451 target genes in maspin cells, compared with mock cells. The fold of relative protein expression of $(\mathrm{G})$ miR-21 target genes, $(\mathrm{H})$ miR-10b target genes and (I) miR-451 target genes. Data are presented as the mean \pm standard deviation from a single experiment in duplicate, representative of $\geq 3$ separate experiments. $\beta$-actin was the loading control. ${ }^{*} \mathrm{P}<0.05$ vs. mock; ${ }^{* *} \mathrm{P}<0.01$ vs. mock. miR, microRNA; PTEN, phosphatase and tensin homolog; PDCD4, programmed cell death 4; Bcl-2, B-cell lymphoma-2; MDR1, multi-drug resistance gene 1; HOXD10, homeobox D10.

with an anti-miR-21 inhibitor resulted in the inhibition of proliferation and invasion of MCF-7 cells; conversely, the transfection of cells with an anti-miR-10b inhibitor prevented invasion, but did not affect the proliferation of MCF-7 cells. Additionally, transfection of MCF-7 cells with an anti-miR-451 inhibitor did not alter the proliferation or invasion of cells. These results were consistent with those of prior studies that explored the functions of miR-21, miR10b and miR-451 in other types of tumor cells (27-29).

The results of the present study demonstrated that maspin inhibits the invasion and proliferation of MCF-7 cells, and is dependent on the downregulation of miR-21 expression and the upregulation of target gene expression. Identifying the underlying molecular mechanisms by which maspin inhibits the invasion and proliferation of cancer cells will be beneficial for the management of breast cancer.

\section{Acknowledgements}

Not applicable.

\section{Funding}

The authors acknowledge funding from National Natural Science Foundation of China (grant nos. 81460514, 71463030 

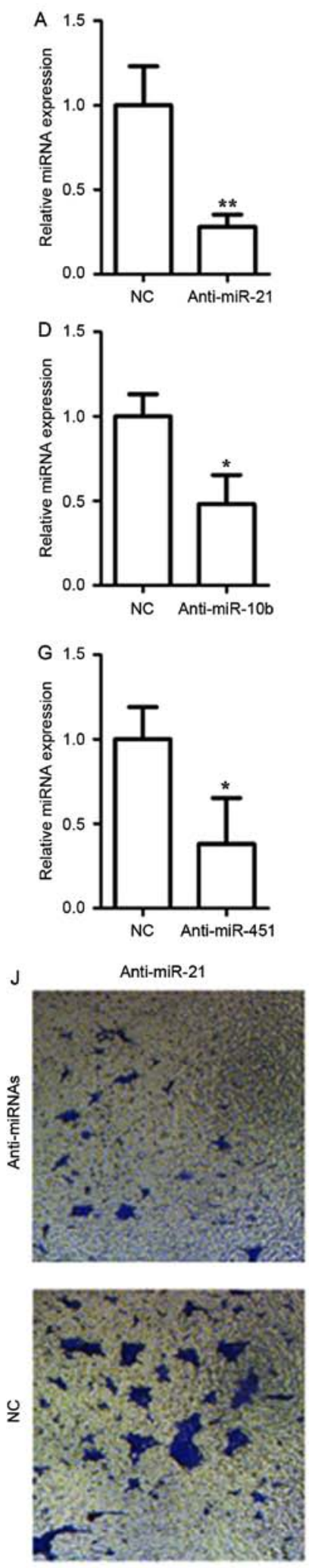
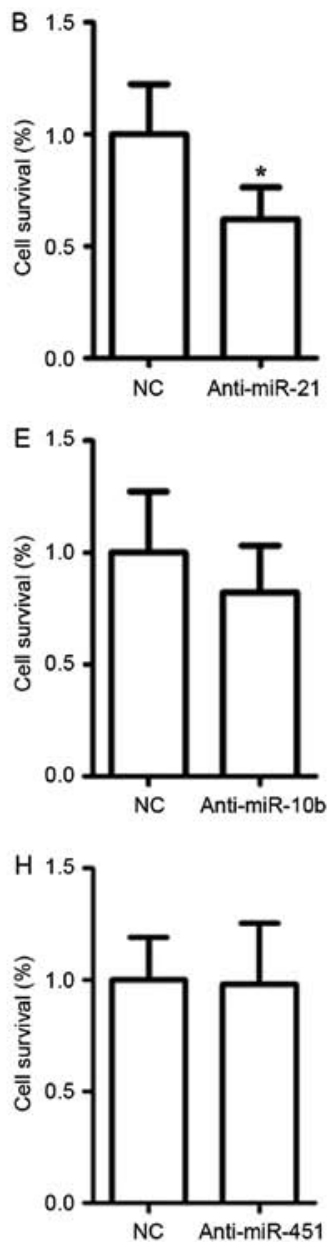

Anti-miR-10b
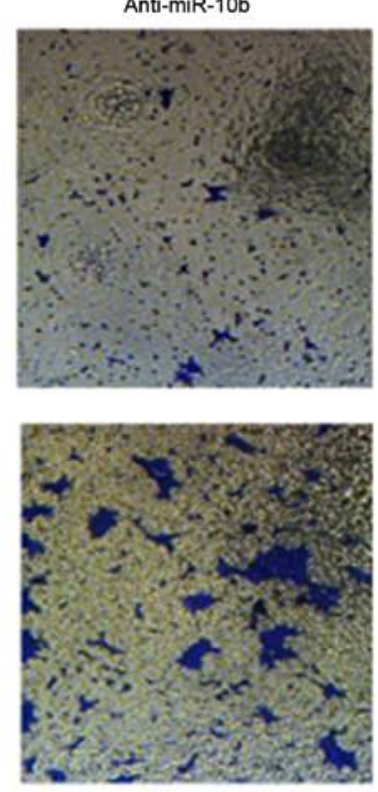
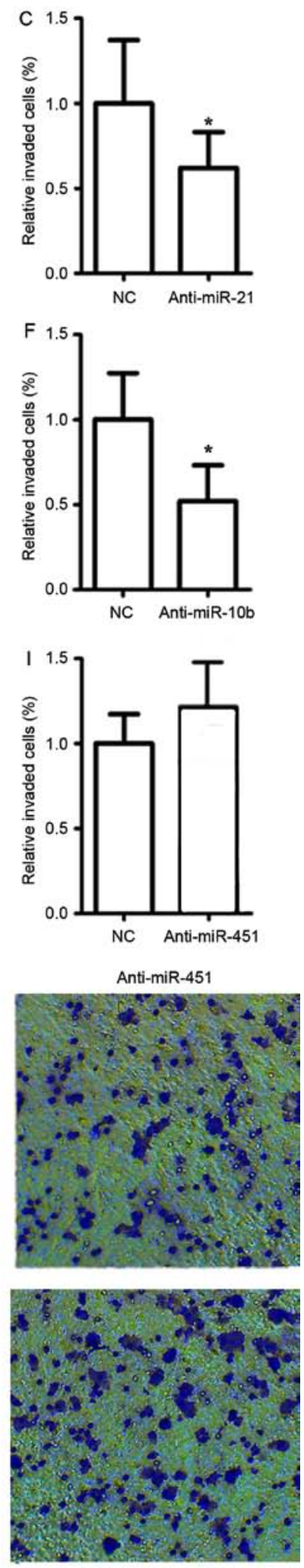

Invasion

Figure 4. Knockdown the expression of miR-21, miR-10b and miR-451 decreased cell survival and cell invasion. Effect of miR-21, miR-10b and miR-451 on the proliferation and invasion of MCF-7 cells. (A) MCF-7 cells were transfected with anti-miR-21, and RT-qPCR was used to verify the transfection effect (B) Cell Counting Kit- 8 were used for measuring the change of proliferation of cells following transfection with anti-miR-21. (C) The results of relative invaded cells with anti-miR-21 were measured by Transwell invasion assays. (D) MCF-7 cells were transfected with anti-miR-10b, and RT-qPCR was used to verify the transfection effect (E) Cell Counting Kit-8 were used for measuring the cells survival following transfection with anti-miR-10b. (F) Cells transfected with anti-miR-10b were collected for measuring migration by Transwell invasion assays. (G) MCF-7 cells were transfected with anti-miR-451, and RT-qPCR was used to verify the transfection effect of miR-451. (H) Cells were collected for measuring the proliferation of cells using Counting Kit-8. (I) Cells transfected with anti-miR-451 were collected for measuring migration by Transwell invasion assays. (J) Images (x200 magnification) of the invasion assay with representative fields from each experiment. Data are presented as the mean \pm standard deviation from three independent experiments. * $\mathrm{P}<0.05$ vs. miR-control; ${ }^{* * *} \mathrm{P}<0.01$ vs. miR-control. miR, microRNA; NC, negative control. 
and 81360447), the Natural Science Foundation of Jiangxi (grant no. 20151BAB205065) and Jiangxi Natural Science Foundation (grant no. 20181BAB205067.

\section{Availability of data and materials}

All data generated or analyzed during this study were included in this published article.

\section{Authors' contributions}

SXH conceived and designed the study. WYF, LW, HL, XW and $\mathrm{HZ}$ performed the experiments. WBJ analyzed the results. SXH wrote, reviewed and edited the manuscript. All authors read and approved the manuscript.

\section{Ethics approval and consent to participate}

Not applicable.

\section{Patient consent for publication}

Not applicable.

\section{Competing interests}

The authors declare that they have no competing interests.

\section{References}

1. Benson JR, Jatoi I, Keisch M, Esteva FJ, Makris A and Jordan VC: Early breast cancer. Lancet 373: 1463-1479, 2009.

2. Siegel R, Naishadham D and Jemal A: Cancer statistics, 2012. CA Cancer J Clin 62: 10-29, 2012.

3. Latha K,Zhang W, Cella N, Shi HY and Zhang M: Maspin mediates increased tumor cell apoptosis upon induction of the mitochondrial permeability transition. Mol Cell Biol 25: 1737-1748, 2005.

4. Shay JW and Roninson IB: Hallmarks of senescence in carcinogenesis and cancer therapy. Oncogene 23: 2919-2933, 2004.

5. Bodenstine TM, Seftor RE, Khalkhali-Ellis Z, Seftor EA, Pemberton PA and Hendrix MJ: Maspin: Molecular mechanisms and therapeutic implications. Cancer Metastasis Rev 31: 529-551, 2012.

6. Hill SM and Blask DE: Effects of the pineal hormone melatonin on the proliferation and morphological characteristics of human breast cancer cells (MCF-7) in culture. Cancer Res 48 : 6121-6126, 1988.

7. Lagos-Quintana M, Rauhut $\mathrm{R}$, Lendeckel $\mathrm{W}$ and Tuschl $\mathrm{T}$ : Identification of novel genes coding for small expressed RNAs. Science 294: 853-858, 2001.

8. Lau NC, Lim LP, Weinstein EG and Bartel DP: An abundant class of tiny RNAs with probable regulatory roles in Caenorhabditis elegans. Science 294: 858-862, 2001.

9. Lee RC and Ambros V: An extensive class of small RNAs in Caenorhabditis elegans. Science 294: 862-864, 2001.

10. Tie Y, Liu B, Fu H and Zheng X: Circulating miRNA and cancer diagnosis. Sci China C Life Sci 52: 1117-1122, 2009.

11. Roth C, Rack B, Müller V,Janni W, PantelK and Schwarzenbach H: Circulating microRNAs as blood-based markers for patients with primary and metastatic breast cancer. Breast Cancer Res 12: R90, 2010.

12. Bacus SS, Kiguchi K, Chin D, King CR and Huberman E: Differentiation of cultured human breast cancer cells (AU-565 and MCF-7) associated with loss of cell surface HER-2/neu antigen. Mol Carcinog 3: 350-362, 1990.
13. Shi JA, Lu DL, Huang $X$ and Tan W: miR-219 inhibits the proliferation, migration and invasion of medulloblastoma cells by targeting CD164. Int J Mol Med 34: 237-243, 2014.

14. Wilks DS (ed): Chapter 15-Cluster analysis, in international geophysics. Academic Press, pp603-616, 2011.

15. Liu CL, Prapong W, Natkunam Y, Alizadeh A, Montgomery K, Gilks CB and van de Rijn M: Software tools for high-throughput analysis and archiving of immunohistochemistry staining data obtained with tissue microarrays. Am J Pathol 161: 1557-1565, 2002.

16. Livak KJ and Schmittgen TD: Analysis of relative gene expression data using real-time quantitative PCR and the 2(-Delta Delta C(T)) method. Methods 25: 402-408, 2001.

17. Huang S, Ye J, Yu J, Chen L, Zhou L, Wang H, Li Z and Wang C: The accumulation and efflux of lead partly depend on ATP-dependent efflux pump-multidrug resistance protein 1 and glutathione in testis Sertoli cells. Toxicol Lett 226: 277-284, 2014.

18. Zou Z, Anisowicz A, Hendrix MJ, Thor A, Neveu M, Sheng S, Rafidi K, Seftor E and Sager R: Maspin, a serpin with tumor-suppressing activity in human mammary epithelial cells. Science 263: 526-529, 1994.

19. Berardi R, Morgese F, Onofri A, Mazzanti P, Pistelli M, Ballatore Z, Savini A, De Lisa M, Caramanti M, Rinaldi S, et al: Role of maspin in cancer. Clin Transl Med 2: 8, 2013.

20. Meng F, Henson R, Wehbe-Janek H, Ghoshal K, Jacob ST and Patel T: MicroRNA-21 regulates expression of the PTEN tumor suppressor gene in human hepatocellular cancer. Gastroenterology 133: 647-658, 2007.

21. Zhang S, Li J, Jiang Y, Xu Y and Qin C: Programmed cell death 4 (PDCD4) suppresses metastastic potential of human hepatocellular carcinoma cells. J Exp Clin Cancer Res 28: 71, 2009.

22. Wickramasinghe NS, Manavalan TT, Dougherty SM, Riggs KA, Li Y and Klinge CM: Estradiol downregulates miR-21 expression and increases miR-21 target gene expression in MCF-7 breast cancer cells. Nucleic Acids Res 37: 2584-2595, 2009.

23. Dong S, Ma W, Hao B, Hu F, Yan L, Yan X, Wang Y, Chen Z and Wang Z: microRNA-21 promotes cardiac fibrosis and development of heart failure with preserved left ventricular ejection fraction by up-regulating Bcl-2. Int J Clin Exp Pathol 7: 565-574, 2014.

24. Ma L, Teruya-Feldstein $\mathrm{J}$ and Weinberg RA: Tumour invasion and metastasis initiated by microRNA-10b in breast cancer. Nature 449: 682-688, 2007.

25. Makiyama K, Hamada J, Takada M, Murakawa K, Takahashi Y, Tada M, Tamoto E, Shindo G, Matsunaga A, Teramoto K, et al: Aberrant expression of HOX genes in human invasive breast carcinoma. Oncol Rep 13: 673-679, 2005.

26. Xiao HB, Li H, Yu G, Xiao W, Hu J, Tang K, Zeng J, He W, Zeng $\mathrm{G}, \mathrm{Ye} \mathrm{Z}$ and $\mathrm{Xu} \mathrm{H}$ : MicroRNA-10b promotes migration and invasion through KLF4 and HOXD10 in human bladder cancer. Oncol Rep 31: 1832-1838, 2014.

27. Zhang Z, Li Z, Gao C, Chen P, Chen J, Liu W, Xiao S and Lu H: miR-21 plays a pivotal role in gastric cancer pathogenesis and progression. Lab Invest 88: 1358-1366, 2008.

28. Asangani IA, Rasheed SA, Nikolova DA, Leupold JH, Colburn NH, Post S and Allgayer H: MicroRNA-21 (miR-21) post-transcriptionally downregulates tumor suppressor Pdcd4 and stimulates invasion, intravasation and metastasis in colorectal cancer. Oncogene 27: 2128-2136, 2008.

29. Hiyoshi Y, Kamohara H, Karashima R, Sato N, Imamura Y, Nagai Y, Yoshida N, Toyama E, Hayashi N, Watanabe M, et al: MicroRNA-21 regulates the proliferation and invasion in esophageal squamous cell carcinoma. Clin Cancer Res 15: 1915-1922, 2009.

This work is licensed under a Creative Commons Attribution-NonCommercial-NoDerivatives 4.0 International (CC BY-NC-ND 4.0) License. 